\title{
Hospitality Major Vocational High School Students' Expectations on University Education
}

\author{
Ya-Ting Chung ${ }^{1} \&$ Cheng-Cheng Yang ${ }^{2}$ \\ ${ }^{1}$ Graduate Institute of Educational Administration and Policy Development, National Chiayi University, Taiwan \\ ${ }^{2}$ National Chiayi University, Taiwan \\ Correspondence: Cheng-Cheng Yang, Assistant Professor, National Chiayi University, Taiwan. Tel: \\ 886-5-226-3411. E-mail: yccjason@mail.ncyu.edu.tw
}

Received: May 23, 2013 Accepted: June 22, 2013 Online Published: July 18, 2013

doi:10.5539/hes.v3n4p60 URL: http://dx.doi.org/10.5539/hes.v3n4p60

\begin{abstract}
Hospitality is not a new industry in Asia, but high quality hospitality industry has become more and more important in the trend of questing service-based economy and the increasing number of tourists in Asia. Thus there are more universities opened hospitality degree programs in Asia, Taiwan is no exception. In this context, why high school graduates will choose hospitality as their college major? What are their expectations on their future education experience in the hospitality program? To answer the above questions, this research adopted semi-structured interview as research method. Ten vocational high school students in Taiwan were interviewed in this research. This research generated similarities and differences of opinions among these ten students, students generally thought university education can help their employability in the future because their enhancement of professional skills and knowledge. Their expectations of an ideal hospitality program environment include well-prepared equipment, industrial and international internship opportunities, and international campaign participation. In terms of the key elements of hospitality courses and curricula, students expect internationalized content and quality, professional technical training, foreign language training, management ability, and interdisciplinary content.
\end{abstract}

Keywords: hospitality program, higher education, vocational high school, Taiwan

\section{Introduction}

In response to the global higher education competition, universities all try to enhance their quality and form school features to attract students. In the recent years, hospitality industry became a significant business in the world because of the emerging globalization. This trend is no exception in the Asia region. In fact, high quality hospitality industry has become more and more important in the trend of questing service-based economy and the increasing number of tourists in Asia. Thus there are more universities opened hospitality degree programs in Asia, Taiwan is no exception. In the academic year of 2011, the total number of hospitality bachelor degree program students in Taiwan is 15,526 and it ranked as the top ten programs in terms of student number when comparing it with the other bachelor programs in Taiwan (Ministry of Education in Taiwan, 2013). In the academic year of 2012, the number of total hospitality major bachelor students grew to 17,170 (Ministry of Education in Taiwan, 2013).

In this context, why high school graduates will choose hospitality as their major? What are their expectations on their future education experience in the hospitality program? To answer the above questions, this research adopted semi-structured interview as research method. Ten vocational high school students in Taiwan were interviewed in this research. This research plans to generate similarities and differences of opinions among these ten students. Through this study, it can be expected to understand the reasons why students make the decision of attending university, allowing universities to increase their quality based on the needs of students. To explore students' needs can also help program directors to design their curriculums and create an environment of willingness to learn and a sense of accomplishment.

Therefore, the research purposes of this research are to accomplish the following three research purposes. 1. To explore the reason why hospitality major vocational school students will choose to attend college in the future. 2 . To know hospitality major vocational school students' thinking in the process of their cognitive perceptions of 
selecting their favorite college major. 3. To know hospitality major vocational school students' thinking in the process of their cognitive perceptions of selecting their favorite college. 4. To know hospitality major vocational school students' cognitive perceptions of expected ideal college environment. 5. To know hospitality major vocational school students' cognitive perceptions of their career aspiration after finishing their college degree.

\section{Review of the Related Literatures}

\subsection{Vocational High School Student's Education Pathway and Career Aspiration}

In Taiwan, vocational high school students generally have fewer four-year comprehensive university education opportunities before the mass expansion of higher education after 1990s (Wang, 2003). The system of higher education in Taiwan put vocational high schools an important role of training students fit the job market and thus the nation can get direct economic benefits from this track. Before the year of 1990s, the original upward education opportunities for vocational high school students in Taiwan are junior colleges. And after the years of 1990s, many of the junior colleges were upgraded as four-year universities of technology (Wang, 2003). These universities of technology in Taiwan offer bachelor degree programs for vocational high school graduates and more and more general universities and technical universities offered hospitality related degree programs in Taiwan.

Bai (2006) analyzed the higher education policy change in China, and he found out that it is an observable trend that Chinese parents are always willing to invest their children's education. Thus the Chinese government linked the expansion of higher education and the stimulation of domestic consumption because of the social preference of having a bachelor degree.

Community colleges in the United States play a similar role as vocational high schools and junior colleges in Taiwan. In the United States, the system does not differentiate high schools into academic and vocational track, but the United States differentiates its higher education system into academic and community institutions. Community college, based on Bragg's (2001) analysis, has the functions of transfer, vocational, developmental, and continual education. Bragg (2001) also pointed out the debates of curriculum change in community colleges. Some scholars see the inclusion of transfer and vocational into curriculum is good for all students, some do not support this idea.

In the United States, the fee of attending community college is lower than attending academic institution, thus the price issue does affect students' decision of whether going to community college or academic university. Hilmer (1998) found out to either increasing academic university fees or decreasing community college fees can encourage students to enroll in community college right after high school. But the situation in Taiwan is different. The fees of vocational university and academic university are similar, thus to find out why students made the decision of attending vocational university is an important elaboration of existed literatures.

The original design of vocational high school is to help students receive vocational training and practical internship. To prepare students success in the job market right after graduation is its goal. Since the higher education systems in different countries entered the phase of mass type or universal access type of higher education, there are more vocational oriented universities and colleges established. More vocational high school students see enrolling in university and college as their goal after graduation instead of being employed immediately after graduation. Therefore, how vocational high school students view university education, what are their expectations on university education become an important topic. Phillips, Blustein, Jobin-Dvia, and White (2002) found out if high school can offer students work-based learning and introduce students the actual work environment can help students' readiness of school-to-work transition. Also, if high school students can make good use of school resources, then they would be more likely to have clearer transitional plans after graduation.

\subsection{Hospitality Major Students' Perceptions about Their Higher Education Experience}

Woodley, Wagner, Slowey, Hamilton, and Fulton (1987) distinguished the learning motivations of adult students into nine types of goal, these goals relating with the concepts of career development, social relationship, escape of real life, personal fulfillment, gaining practical skill, and etc. Thus to explore why students choose a specific major during their learning process in the universities can find some clues from the above factors. O'Mahony, McWilliams, and Whitelaw (2001) adopted focus group and questionnaire survey to hospitality major students and they found only ten percent of the samples reported that they decided to work in hospitality before entering the university. Many students reported that they study in the hospitality degree program because of the positive perceptions of the hospitality industry. One important influencer of choosing this program, students said is because of the one year internship opportunity for hospitality students. Chuang and Dellmann-Jenkins (2010) 
adopted survey method and administered a total of 360 questionnaires to undergraduate students major in hospitality, they found out students' reasons of pursuing a hospitality profession, ranking from the highest frequency to lower, include people interaction, personal interests, love the hospitality industry, employability, and loving the nature of hospitality. They also found out the intrinsic reward is the most important factor that to drive these students to make a career decision. This means if the work environment can fulfill students' inner motivation, then their involvement into this work will be much higher.

\section{Research Method}

This research chooses one vocational high school as the research field. This school is located in a sub-urban city in the southern part of Taiwan. This school is founded in the year of 1978. The number of total teachers is about 133 and the total number of students is about four thousands. The programs of this high school include information studies, early childhood educare, cosmetology and image design, information studies, tourism, and hospitality. This research selected ten third grade hospitality major students. Five male and five female students. To balance their social economic background and professional background. We applied purposive sampling method.

Table 1. Research participants' parental occupation and technical certificates

\begin{tabular}{|c|c|}
\hline $\begin{array}{l}\text { Research Participants' Background } \\
\text { Information }\end{array}$ & Number \\
\hline Gender & Five male and five female \\
\hline Parental Occupation & Two of Agriculture, Six of Service, Two of Engineer. \\
\hline Technical Certificates & $\begin{array}{l}\text { Ten of Chinese food cooking, Ten of restaurant service, } \\
\text { Seven of computer software level 3, Three of homepage } \\
\text { design. }\end{array}$ \\
\hline
\end{tabular}

This research adopted semi-structure interview method to collect data from these ten students. The aims of our interview are to know these students perceptions of reasons of selecting college majors and college, to know their ideal image of college environment, and to know their career aspirations. The interview questions include the following eight questions: (1) Do you want to continue your college education after high school? (2) If the answer is yes, then why, please elaborate (3) what kind of department are you going to major in college? (4)What are the reasons that you select that major? (5) What kind of resources that you wish university offers you? (6) What kind of courses do you hope college and university can offer you? (7) What are your career aspirations in the future after you finish your college degree?

\section{Research Results}

\subsection{Hospitality Major Vocational High School Student's Perspectives on Attending College}

All ten students state that they would like to continue their education and will attend college after their vocational high school degree. When the researchers asked them why they want to continue their education, four of them said they believed holding bachelor degree can help them success in the job market and help them find their jobs easily. Three of them stated that they hope they can learn more from university programs. Two out of them said they believed they can enhance their own professional skills and knowledge in the university. One of them said the choice of preparing to attend college is because of parental expectation. 


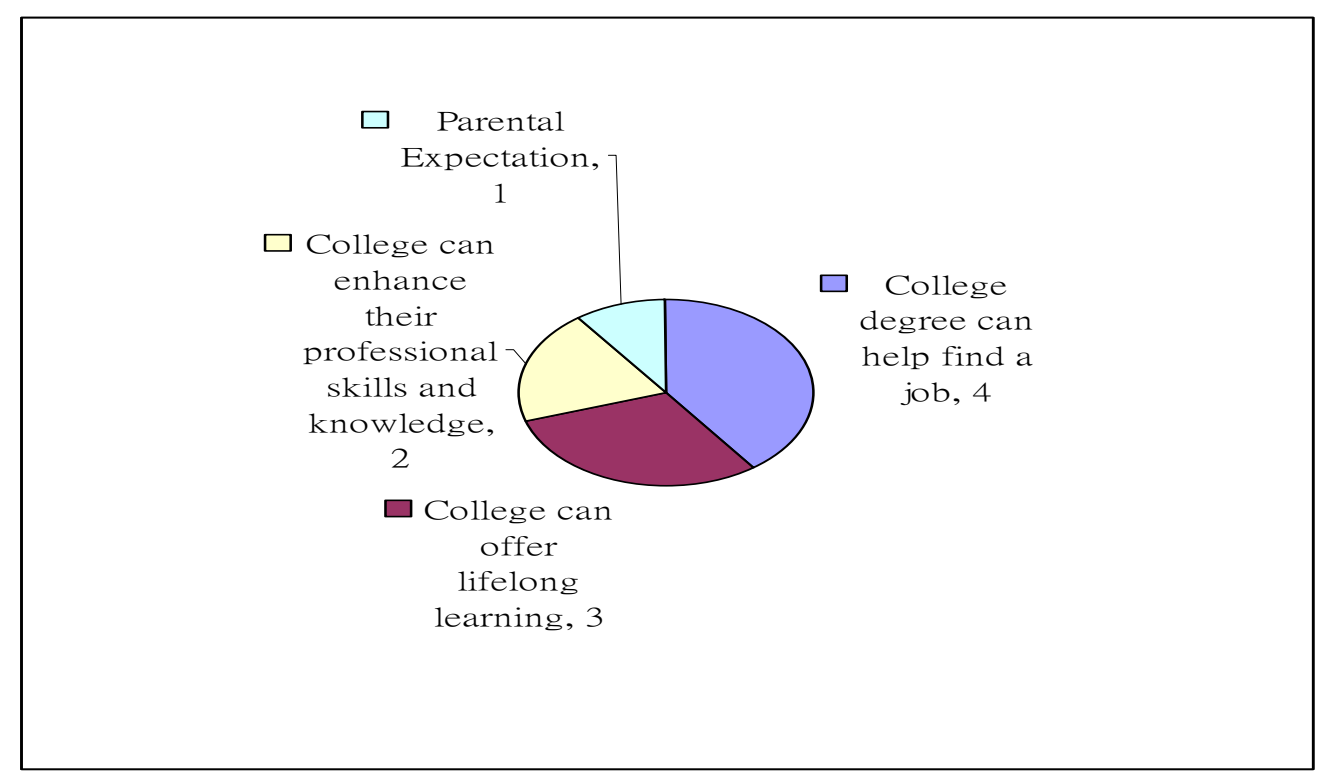

Figure 1. Hospitality major vocational school students' motivations of attending college

I believe university can help me learn more skills and help me find a good job in the future. (Student A-Interview Transcript-20130430)

My mother hope I can continue my education, at least to hold a bachelor degree, they hope I can attend university because my parents regretted not been able to study in the past due to economic difficulty. (Student B-Interview Transcript-20130430)

In terms of the question what kind of major they would like to choose when they attend university in the future, ten students all said that they would like to continue majoring in hospitality. When the researchers asked them the reasons of selecting this major, seven of them said they are really interested in hospitality management. Two of them said because they already learned skills and knowledge of hospitality, they hope they can strengthen their professional skills inside university based on what they already learned in vocational high school. One of them said the major of hospitality can respond the basic needs of citizens and it is also an emerging industry in the coming service and knowledge based economy in Taiwan.

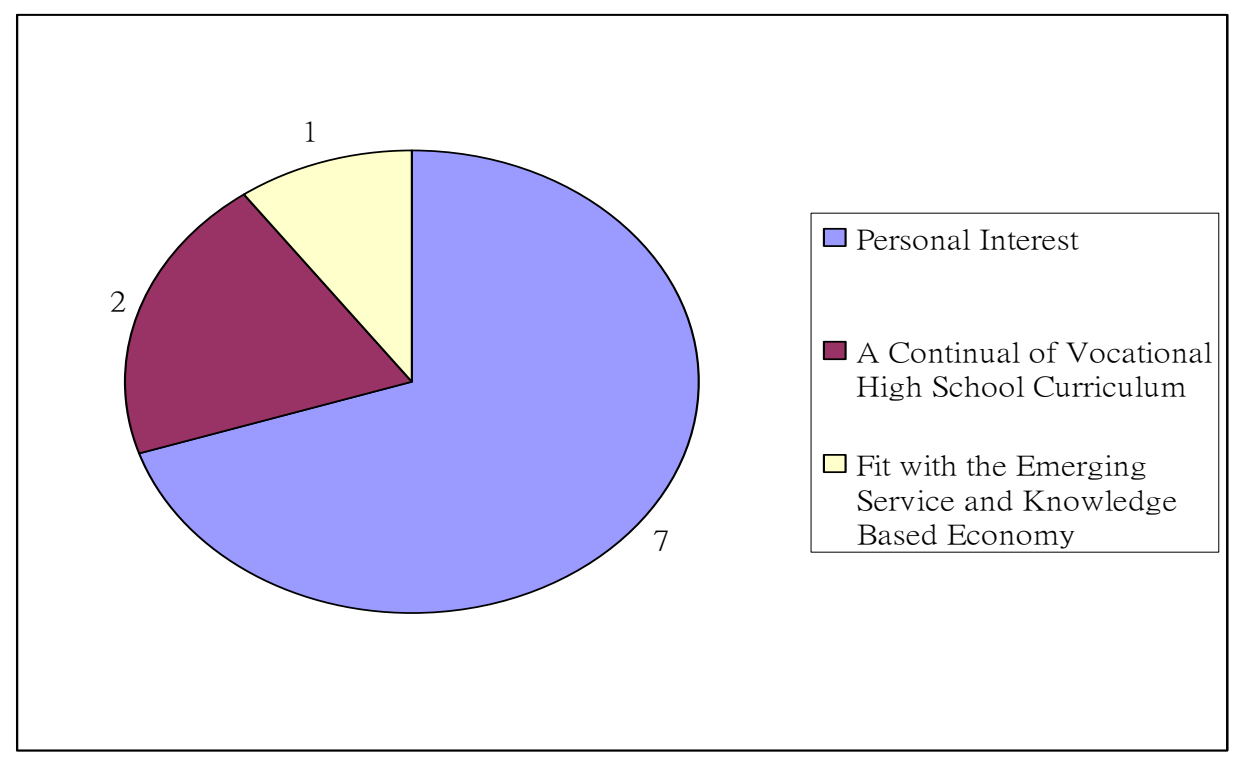

Figure 2. Student's reason of majoring in hospitality in college 
At first, I became interested in hospitality is because my parents owned a restaurant, after the education experiences in vocational high school, I felt I have to learn more professional skills in university. (Student A-Interview Transcript-20130430)

I had some successful experiences during my learning process in this vocational high school, I got many professional licenses. Thus I have confidence to have a successful development in university. (Student B-Interview Transcript-20130430)

\subsection{Hospitality Major Vocational High School Student's Expectations on Higher Education}

When the students were asked about their expectations on higher education and when they are selecting their ideal university, what are the factors they will concern? Three of them mentioned the ideal university is to offer more learning opportunities of professional techniques, two of them said the ideal university is to enhance their employability after graduation. Two of them emphasized the importance of facility quality in the university. Three of them believed reputation and prestigious of the university is the most important.

Table 2. Numbers of students agreed on expectations of higher education

\begin{tabular}{ll}
\hline Expectations on Higher Education & Numbers of Students Agreed \\
\hline Learning opportunities of professional techniques & 3 \\
Enhancing their employability after graduation & 2 \\
Importance of facility quality in university & 2 \\
Reputation and prestigious of higher education & 3 \\
\hline
\end{tabular}

In terms of the resources that vocational high school students hope their future university can offer after they attend, five students said they need well-prepared equipment, two students believed the industrial internship opportunity is the highest priority, one hope university can offer then vocational training so that they can success in the job market, one stated they wish to have study abroad opportunity and learn advanced skills in foreign countries. One student said the opportunity to join the hospitality related campaign, especially those internationally recognized campaign, is the most important opportunity they hope university can offer.

Table 3. Numbers of students agreed on expectations of resources in university

\begin{tabular}{ll}
\hline Expectations on University Resources & Numbers of Students Agreed \\
\hline Well-prepared equipment & 5 \\
Industrial internship opportunity & 2 \\
Vocational training & 1 \\
To learn advanced skills in foreign countries & 1 \\
To join the hospitality related campaign & 1 \\
\hline
\end{tabular}

In terms of the curriculums that vocational high school students hope their future university can offer, three students hope university can offer them technical training related courses. Two of them said they need internationalized content based courses. Two of them mentioned foreign language courses are important. Five of them need management and organizational knowledge courses. One of them hopes they can have cross-disciplinary courses.

I hope university can offer us more internship opportunities, by doing this we can understand job content and actual practice of hospitality. We also hope university can appoint faculty with high professional skills. (Student A-Interview Transcript-20130430)

I hope university can offer us international internship opportunities. Since hospitality is an international field. International internship can help us understand global hospitality management mechanism. (Student B-Interview Transcript-20130430) 
Table 4. Numbers of students agreed on expectations of courses in university

\begin{tabular}{ll}
\hline Expectations on Courses & Numbers of Students Agreed \\
\hline Technical training related courses & 3 \\
Internationalized content based courses & 2 \\
Foreign language courses & 2 \\
Management and organizational knowledge courses & 5 \\
Cross-disciplinary courses & 1 \\
\hline
\end{tabular}

I hope I can enroll in hotel management and human resource management courses in university. I really hope university can strengthen its professional skill curriculums. (Student A-Interview Transcript-20130430)

Besides hospitality courses, I also interested in the expertise of teaching and English language, so I hope the curriculums of the department of hospitality can be diversified. Interdisciplinary is important for college students. (Student B-Interview Transcript-20130430)

\subsection{Hospitality Major Vocational High School Student's Career Aspiration}

In terms of vocational high school student's career aspiration, three of them thought they want to be experts with specific skills in hospitality. Two of them state that they want to be internationalized professions in hospitality. Five of them hope they can be manager in hospitality related industries, and one of them hopes they can incorporate cross-disciplinary knowledge into hospitality management.

Table 5. Numbers of students agreed on their career aspiration

\begin{tabular}{ll}
\hline Career Aspiration & Numbers of Students Agreed \\
\hline Experts with specific skills in hospitality & 3 \\
Internationalized professions in hospitality & 2 \\
Manager in hospitality related industries & 5 \\
$\begin{array}{l}\text { Experts of incorporating cross-disciplinary knowledge into hospitality } \\
\text { management }\end{array}$ & 1 \\
\hline
\end{tabular}

\section{Conclusion}

In this research, hospitality major vocational high school students in Taiwan were participants. The literatures told us that students cared intrinsic motivations when they choose their major and career. The existed researches also pointed out the importance of linking work environment and universities are expected by hospitality major students. This research found out Taiwanese students' decision of attending university were out of the believe of future success in the job market by holding a bachelor degree. But also some of them emphasize their inner interests in the field of hospitality. In terms of how to manage a good hospitality degree program, we can found out professional techniques, employment opportunities, and facility qualities are important factors. Internship opportunities are highly valued by the students, which are similar with existed findings, and the implication of this finding is leaders of technical universities and vocational-oriented universities must prepare and seek more internship programs for their students.

The implication of this research on curriculum design of hospitality program is the interviewees said they need more technical related courses and internationalized contents. Foreign language learning opportunities are also what they need. Management and cross-disciplinary knowledge were also not to be neglected by the hospitality program.

\section{References}

Bai, L. (2006). Graduate unemployment: Dilemmas and challenges in China's move to mass higher education. The China Quarterly, 185, 128-144. http://dx.doi.org/10.1017/S0305741006000087

Bragg, D. D. (2001). Community college access, mission, and outcomes: Considering intriguing intersections and challenges. Peabody Journal of Education, 76(1), 93-116. http://dx.doi.org/10.1207/S15327930PJE7601_06 
Chuang, N. K., \& Dellmann-Jenkins, M. (2010). Career decision making and intention: A study of hospitality undergraduate students. Journal of Hospitality \& Tourism Research, 34(4), 512-530. http://dx.doi.org/10.1177/1096348010370867

Hilmer, M. J. (1998). Post-secondary fees and the decision to attend a university or a community college. Journal of Public Economics, 67, 329-348. http://dx.doi.org/10.1016/S0047-2727(97)00075-3

Ministry of Education in Taiwan. (2013). Top ten total student numbers of bachelor degree programs in Taiwan. Retrieved June 20, 2013, from http://www.edu.tw/pages/detail.aspx?Node=3378\&Page=14083\&Index=5\&WID=31d75a44-efff-4c44-a075 $-15 \mathrm{a} 9 \mathrm{eb} 7 \mathrm{aecdf}$

O'Mahony, G. B., McWilliams, A. M., \& Whitelaw, P. A. (2001). Why students choose a hospitality-degree program: An Australian case study. Cornell Hotel and Restaurant Administration Quarterly, 42, 92-96. http://dx.doi.org/10.1016/S0010-8804(01)90016-3

Phillips, S. D., Blustein, D. L., Jobin-Davia, K., \& White, S. F. (2002). Preparation for the school-to-work transition: The views of high school students. Journal of Vocational Behavior, 61, 202-216. http://dx.doi.org/10.1006/jvbe.2001.1853

Wang, R. J. (2003). From elitism to mass higher education in Taiwan: The problems faced. Higher Education, 46(3), 261-287. http://dx.doi.org/10.1023/A:1025320312531

Woodley, A., Wagner, A., Slowey, L., Hamilton, M., \& Fulton, O. (1987). Choosing to learn: Adults in education. Milton Keynes, U. K.: Open University Press.

\section{Copyrights}

Copyright for this article is retained by the author(s), with first publication rights granted to the journal.

This is an open-access article distributed under the terms and conditions of the Creative Commons Attribution license (http://creativecommons.org/licenses/by/3.0/). 